\title{
Ten years experience in continuing biomedical optics education at Saratov State University
}

\section{Valery Tuchin, Alexander Pravdin}

Valery V. Tuchin, Alexander B. Pravdin, "Ten years experience in continuing biomedical optics education at Saratov State University," Proc. SPIE 2525, 1995 International Conference on Education in Optics, (13 October 1995); doi: $10.1117 / 12.224082$

Event: SPIE's 1995 International Symposium on Optical Science, Engineering, and Instrumentation, 1995, San Diego, CA, United States 
Ten-year experience in continuing biomedical optics education at Saratov State University

$$
\text { V.V.Tuchin, A.B.Pravdin }
$$

Saratov State University, Optics Department Astrakhanskaya 83, Saratov 410071, Russia

E-mail <tuchin@scnit.saratov.su>

Key words: biomedical optics, continuing education, interdisciplinary approach

\section{INTRODUCTION}

Nowadays in Russia, as well as in Europe, problem of the lack of trained specialists in interdisciplinary fields of science and technology, and among them engineers-physicists and physicists-researchers able to collaborate with biologists and physicians at high today's scientific level, is sharply outlined.

As a result, problems are evident in efficiency of employment and development of modern medical diagnostic and therapeutic equipment. Skilled specialists trained in the field of physics and mathematics with substantial knowledge in biology and medicine are needed. Similar situation has been seen in Russia in the field of biophysics in early sixties. Today, in medicine, the growing emphasis is placed on less invasive methods of intervention [1]. The demand of less invasive intervention is best of all met by laser (optical) diagnostic methods and laser treatment. The use of these techniques and laser surgery methods and tools provides shorter hospitalization and rehabilitation time. But the medical personnel and technicians who work now in clinics often can't provide effective, reliable, and safe employment of such intricate equipment as laser units and tools.

However, if for the efficient and safe clinical use of lasers training specialists in the field of laser technology and optical units with very general understanding of medico-biological principles of laser radiation effect on bioobjects seems to be sufficient, in the case of basic medical and biological research the participation of specialist with basic education in biotissue optics, properties of coherent radiation, theory of lasers and fiber optics, laser measurements, and principles of spectroscopy, on the one hand, and physiology, biochemical and biophysical mechanisms of radiation action on living systems, principles of medical diagnosis and objective criteria of treatment, on the other hand, is essential.

In recent years, the need for specialists trained in physics and laser technology and at the same time with the knowledge of biology and medical disciplines is evident in industry. Many plants and research-productive amalgamations with modern high technologies lost the bulk of orders for the cutting of budget allocations to defense (in the US the reduction of defense spending takes place too [1]).

Conversion of industry, the use of high technology facilities for production of technically intricate medical equipment, including laser diagnostic and therapeutical units, is the way out. As a rule, large manufacturers have their own research and design departments, and that is the place where the specialists trained in biomedical optics are needed.

It is University with its traditional developed system of basic education in various fields of natural sciences that is able to train specialists who can on the base of basic knowledge and practical skills perform research and design project on their own. At the same time, basic training and additional training of instructors and lecturers for higher school remain the central task of educational process at University.

Highly qualified faculty, permanent research activity, close relations with research and development divisions of industrial enterprises and with research groups in clinics, all that forms the basis for realization of the principle of continuity in biomedical optics education: physicist/engineer-physicist - Candidate of Science (Ph.D.) Doctor of Science. 


\section{FIELDS OF RESEARCH AND TRAINING}

For ten years works on biomedical optics hold a firm place in research activity of Optics Department of Saratov University. There are many projects that are performed in collaboration with institutes of Russian Academy of Sciences and medical research centers. To our opinion, training students in such substantially interdisciplinary subspecialty as biomedical optics besides understanding by the students basic principles of physical and biomedical disciplines should include early and active participation in real research work. The fields of research work which is performed at Optics Department and collaborating laboratories are the following :

The study of optical properties of eye tissues is conducted as co-work with Laboratory of Laser Medicine of Saratov Branch of Radioegineering and Electronics Institute of Russian Academy of Sciences. For experiments on bio-objects, there were created and are intensively used laser polarizing nephelometer and other computer-aided optical measuring experimental setups. The investigations of biotissues by means of optical-acoustic spectroscopy are performed. Group of researches deals with the problems of mathematical modeling of optical properties of ordered biotissues. Personnel of the laboratory as half-time faculty provides practical training in automation of biomedical research and in computing.

On the base of Laboratory of Laser and Optoelectronic Measuring Systems of Saratov Branch of Mechanical Engineering Institute of Russian Academy of Sciences the Branch of Optics Department was organized [2]. The main field of research activity here is the development of fundamental problems connected with diffraction and interference methods of measurements [3]. As applied to bio-objects the methods of pulse-wave and cardiovibration monitoring, capillary blood and lymph flow analysis based on the dynamics of statistically inhomogeneous speckles, study of epidermis structure by means of laser scanning microscopy are developed.

At the Laboratory of Laser and Optical Methods of Diagnosis and Therapy of Saratov Institute of Rural Hygiene students take part in development of laser and fiber optic equipment for in vivo experiments. They have an opportunity to work with laboratory animals and volunteers. Here the alterations of optical properties of skin and skin physiological response to UV laser irradiation are studied, the techniques of phototesting, laser therapy, and PUVA therapy are developed.

At the Central Research Laboratory of Saratov State Medical University students specializing in biomedical optics can study microscopy techniques: microscopy with image analysis, microphotometry, and microfluorimetry. They can prepare here their annual student projects or diploma thesis (see below) in the field of the effect of low intensity laser radiation on biosystems. At this laboratory the laser speckle-anemometer for biological fluids diagnostics (see the list of special laboratories in biophysics below) is mounted.

Just at the Optics Department, in the Laboratory of Photobiology and Photomedicine, the research activity is concentrated on the study of optical properties of biotissues (absorption spectrophotometry, reflectance spectrophotometry, fluorescence spectroscopy, and resonance Raman spectroscopy), on the theoretical aspects of light propagation within scattering media with absorption, on reverse problem of biotissue optics, and improvement of computational technique. Group of researches is engaged in development of mathematical model of cell dynamics control by low intensity laser radiation.

The active participation of students in biomedical optics research is realized in the frame of curriculum through the work at annual student's project and diploma work and during long-term practical training (see curriculum below), in the case of post-graduate students through research on their own, under the supervision of leading researchers of laboratories. Students may begin their research work just at the first academic year preparing the annual student's project, as a rule, in a form of literature review on the topical problem of biomedical optics, the theme of review being assigned by instructor. Subsequent annual projects include elements of computations and/or experimental work. The results obtained are discussed at special seminar. All students may participate in discussions at the seminar "Topical problems of laser biomedicine". During tenth semester students work at their diploma works. It is a practice when the work is carried out in the laboratory where the student will get position. The best results usually serve as a basis for publications or presentations at conferences. Contributions with students as co-authors was presented at many conferences, such as Biomedical Optics in USA and Europe, in 1992-1995. Some ten students and instructors of Optics Department of Saratov University took part in International Conference on Education in Optics, Sept.-Oct. 1991, St. Petersburg, Russia. 
Let us list some titles of diploma works of the students specializing in biomedical optics: "The investigation of statistical properties of partially developed speckle-fields in analysis of human epidermis structure", "The development of breadboard model of laser photoerythroelastometer", "Dynamics of epidermis fluorophores photobleaching", "Numerical simulation of light propagation in scattering media with macro inhomogeneities", "The use of resonance Raman spectroscopy for detection of carotene in human blood serum".

During last five years Optics Department established close contacts with world biomedical optics community. Some ten professors and researchers are the members of BiOS (Biomedical Optics Society), and representatives of the Department take part almost in all BiOS supported events. Optics Department performs active scientific and educational exchange with the research and educational centers from the USA, Germany, the Netherlands. Some joint research is conducted by our researchers at our partners' laboratories, and our professors deliver lectures abroad. In turn, leading foreign experts in biomedical optics deliver lectures to our undergraduates and postgraduate students. Two students study current academic year in USA:- undergraduate student studies and prepared her diploma thesis on optical properties of scattering phantoms of living tissue at Middlebury college, Vermont;- postgraduate student works at his Ph.D. thesis and participates in research on development of optical diagnostics methods at Pennsylvania University, Philadelphia. stipend.

This year five students of Optics Department were awarded the title "Soros Student" and got the ISF

\section{CURRICULUM OF "BIOMEDICAL OPTICS" SUBSPECIALTY}

Training in specialty "physics" (biomedical optics being one of the subspecialties of it) takes five academic years. During first three years students get fundamental knowledge in mathematics and physics. Common curriculum for the specialty is shown in Table 1. Just at the first year from the course "Introduction into specialty" students gain the impression about biomedical optics research that is performed at Optics Department. Specialized training begins according to current curriculum from the third year. Disciplines of the specialization "biomedical optics" are listed in Table 2.

Table 1. Common curriculum for specialty "Physics"

\begin{tabular}{|c|c|c|c|c|c|c|c|}
\hline \multirow[b]{2}{*}{ Disciplines } & Exam & Pass- & \multicolumn{5}{|c|}{ Hours } \\
\hline & \multicolumn{2}{|c|}{$\begin{array}{l}\text { The number of } \\
\text { the corres- } \\
\text { ponding } \\
\text { semester }\end{array}$} & Total & $\begin{array}{l}\text { Lectu- } \\
\text { res }\end{array}$ & $\begin{array}{l}\text { Labo- } \\
\text { ratory }\end{array}$ & $\begin{array}{l}\text { Prac- } \\
\text { tical } \\
\text { trng }\end{array}$ & $\begin{array}{l}\text { Semina } \\
\mathrm{rs} / \mathrm{trng}\end{array}$ \\
\hline 1. Political history of XX century & 1 & 2 & 120 & 40 & & & $60 / 20$ \\
\hline 2. Philosophy & 4 & 3 & 140 & 56 & & & $60 / 24$ \\
\hline 3. Political economy & 6 & 5 & 140 & 54 & & & $62 / 24$ \\
\hline 4. Sociology & 9 & 8 & 80 & 34 & & & $34 / 12$ \\
\hline $\begin{array}{l}\text { 5. History of religion and } \\
\text { atheism }\end{array}$ & & 9 & 24 & 24 & & & \\
\hline 6. Fundamentals of law & & 9 & 32 & 28 & & & 14 \\
\hline $\begin{array}{l}\text { 7. Labour protection and } \\
\text { protection of environment }\end{array}$ & & 1 & 36 & 36 & & & \\
\hline 8. Foreign language & 6 & $3,4,5$ & 260 & & & 180 & 136 \\
\hline $\begin{array}{l}\text { 9. Introduction into the } \\
\text { specialty }\end{array}$ & & & 18 & 18 & & & \\
\hline $\begin{array}{l}\text { 10. Seminar on annual student } \\
\text { project and diploma work }{ }^{*} \text { ) }\end{array}$ & & $\begin{array}{c}2,4,6,8 \\
, 10 \\
\end{array}$ & 86 & & & & 186 \\
\hline $\begin{array}{l}\text { 11. Higher mathematics: } \\
\text { a) mathematical analysis } \\
\text { b) analytical geometry and } \\
\text { higher algebra } \\
\text { c) principles of vector and }\end{array}$ & $\begin{array}{c}1,2,3 \\
2\end{array}$ & 1,2 & $\begin{array}{l}406 \\
140\end{array}$ & $\begin{array}{c}212 \\
70\end{array}$ & & $\begin{array}{l}106 \\
35\end{array}$ & $\begin{array}{l}188 \\
135\end{array}$ \\
\hline
\end{tabular}




\begin{tabular}{|c|c|c|c|c|c|c|c|}
\hline $\begin{array}{l}\text { tensor analysis } \\
\text { d) differential and integral } \\
\text { equations } \\
\text { e) probability theory and } \\
\text { mathematical statistics }\end{array}$ & 3 & 6 & $\begin{array}{l}54 \\
72 \\
68 \\
\end{array}$ & $\begin{array}{l}36 \\
36 \\
34 \\
\end{array}$ & & $\begin{array}{l}18 \\
18 \\
17\end{array}$ & $\begin{array}{l}/ 18 \\
/ 17\end{array}$ \\
\hline $\begin{array}{l}\text { 12. General physics: } \\
\text { a) mechanics } \\
\text { b) molecular physics } \\
\text { c) electricity and magnetism } \\
\text { d) optics } \\
\text { e) physics of atom } \\
\text { f) nuclear physics and } \\
\text { physics of elementary } \\
\text { particles } \\
\end{array}$ & $\begin{array}{l}1 \\
2 \\
3 \\
4 \\
5\end{array}$ & $\begin{array}{l}1 \\
2 \\
3 \\
4\end{array}$ & $\begin{array}{c}126 \\
119 \\
126 \\
119 \\
90 \\
\\
34\end{array}$ & $\begin{array}{l}72 \\
68 \\
72 \\
68 \\
54\end{array}$ & & $\begin{array}{l}36 \\
34 \\
36 \\
34 \\
18\end{array}$ & $\begin{array}{l}/ 18 \\
/ 17 \\
/ 18 \\
/ 17 \\
/ 18\end{array}$ \\
\hline 13. Practical training in physics & & $1-6$ & 403 & & 210 & & $/ 193$ \\
\hline $\begin{array}{l}\text { 14. Physical principles of } \\
\text { radioengineering }\end{array}$ & 4 & 4 & 119 & 51 & 68 & & \\
\hline $\begin{array}{l}\text { 15. Theoretical physics: } \\
\text { a) methods of mathematical } \\
\text { physics } \\
\text { b) analytical mechanics } \\
\text { c) theory of continuous } \\
\text { media } \\
\text { d) quantum mechanics } \\
\text { e) electrodynamics } \\
\text { f) thermodynamics and } \\
\text { statistical physics } \\
\text { g) solid state physics }\end{array}$ & $\begin{array}{l}7 \\
5 \\
7 \\
8 \\
8\end{array}$ & $\begin{array}{l}4 \\
5 \\
6 \\
4 \\
6\end{array}$ & $\begin{array}{c}106 \\
68 \\
\\
54 \\
140 \\
140 \\
140 \\
51 \\
\end{array}$ & $\begin{array}{l}53 \\
34 \\
\\
36 \\
70 \\
70 \\
70 \\
74 \\
\end{array}$ & $\begin{array}{l}35 \\
35 \\
35\end{array}$ & & $\begin{array}{l}/ 18 \\
/ 17 \\
118 \\
135 \\
135 \\
135 \\
117\end{array}$ \\
\hline $\begin{array}{l}\text { 16. Computing: } \\
\text { a) computers and } \\
\text { programming } \\
\text { b) computational methods } \\
\text { in physics } \\
\text { c) data banks, knowledge } \\
\text { bases, and data-base } \\
\text { management systems } \\
\text { d) system analysis } \\
\text { e) numerical simulation in } \\
\text { physics } \\
\text { f) computer-aided research } \\
\text { and development } \\
\text { g) computer-aided design } \\
\text { systems }\end{array}$ & 8 & $\begin{array}{l}1 \\
3\end{array}$ & $\begin{array}{l}18 \\
36 \\
68 \\
36 \\
36\end{array}$ & $\begin{array}{l}53 \\
18 \\
18 \\
36 \\
17 \\
18 \\
18\end{array}$ & $\begin{array}{l}34 \\
18 \\
18\end{array}$ & 17 & $\begin{array}{l}135 \\
/ 18\end{array}$ \\
\hline $\begin{array}{l}\text { 17. Foundations of research and } \\
\text { engineering }\end{array}$ & & 8 & 34 & 34 & & & \\
\hline 18. Management & & 9 & 36 & 18 & & 18 & \\
\hline $\begin{array}{l}\text { 19. Disciplines of } \\
\text { specialization }\end{array}$ & $\begin{array}{l}7,7,8 \\
8,9,9\end{array}$ & $\begin{array}{c}6,7,7,7 \\
8,8,8 \\
9,9 \\
\end{array}$ & 722 & 378 & 212 & & $/ 132$ \\
\hline $\begin{array}{l}\text { 20. Civil defense } \\
\text { 21. Sports } \\
\text { 22. Military training }\end{array}$ & 6,8 & $\begin{array}{c}2 \\
1-8 \\
5,7 \\
\end{array}$ & $\begin{array}{c}50 \\
560 \\
440 \\
\end{array}$ & $\begin{array}{r}40 \\
350 \\
\end{array}$ & & 420 & $\begin{array}{c}110 \\
/ 140 \\
/ 90 \\
\end{array}$ \\
\hline
\end{tabular}

*) Diploma work $\approx$ master's thesis. At the end of the first, second, third, and fourth year - defense of the annual student projects. 
Optional disciplines

1 Ethics and aesthetics

2 History of the world and home culture

3 Second foreign language

Long-term practical training:

$\begin{array}{llr}\text { Computing after } & 4 \text { semester } & 2 \text { weeks } \\ \text { Engineering after } & 7 \text { semester } & 2 \text { weeks } \\ \text { Prediploma at } & 9 \text { semester } & 10 \text { weeks }\end{array}$

Defense of the diploma work.

Table 2. Curriculum for specialization "Biomedical Optics"

\begin{tabular}{|l|c|c|c|}
\hline \multicolumn{1}{|c|}{ Disciplines } & Hours & Semester & Exam/Pass-exam \\
\hline 1. Introduction into cell biology & 34 & 6 & pass-exam \\
2. Theory of radiation & 36 & 7 & exam \\
3. Introduction into physics of lasers & 36 & 7 & pass-exam \\
4. Theoretical optics & 36 & 7 & exam \\
5. Holography and optical information processing & & & \\
6. Foundations of biochemistry and biophysics of photobiological & 36 & 7 & pass-exam \\
processes & 72 & 7 & \\
7. Special practical physics - 1 & 72 & 7 & pass-exam \\
8. Statistical optics & 51 & 8 & \\
9. Atomic and molecular spectroscopy & 51 & 8 & exam \\
10. Special practical physics - 2 & 68 & 8 & exam \\
11. Molecular optics & 34 & 8 & pass-exam \\
12. Diffraction methods in biomedicine & 34 & 8 & pass-exam \\
13. Nonlinear optics & 36 & 9 & exam \\
14. Special practical physics - 3 & 36 & 9 & pass-exam \\
15. Lasers and fiber optics in biomedicine & 36 & 9 & exam \\
16. Luminescence & 36 & 9 & pass-exam \\
17. High-resolution spectroscopy & 18 & 9 & \\
18. Spectroscopy of bio-objects & 36 & 9 & pass-exam \\
\end{tabular}

Some courses are common for all students who have chosen one of the subspecialties of Optics Department. These disciplines prepare students to comprehensive understanding of the mechanisms of light interaction with bio-objects and principles of optical diagnostics and measurements. Lectures on introduction into cell biology and on physiology of man and animals are delivered by lecturers from Biology Department. Courses "Foundations of biochemistry and biophysics of photobiological processes", "Diffraction methods in biomedicine", "Lasers and fiber optics in biomedicine", and "Spectroscopy of bio-objects" have been developed by the lecturers of Optics Department using the literature that encompasses both traditional and modern approaches in biomedical optics and photobiology [4-10].

After five years of training and defense of diploma work students get the grade "physicist/engineerphysicist". Every year 8-12 students get their grades in biomedical optics. Best graduates usually enter postgraduate course and during three years, carry out research work and prepare Candidate Thesis, after defense of which they get the grade of Candidate of Science (corresponds to Ph.D.). At Optics Department the following theses have been prepared: "The features of light scattering by biological structures as applied to laser-aided diagnosis in ophthalmology", "Concentration effects in light scattering by systems of bioparticles", and "Numerical simulation of light propagation within scattering media with absorption". Now six Candidate Theses and two Doctoral Theses in the field of biomedical optics are under preparation. 
In the course of realization of the curriculum we faced the problem that the knowledge of chemistry and biology students get at secondary school is insufficient for successful mastering of disciplines of subspecialty. As a consequence of this we decided to insert ten-hour auxiliary course "Fundamentals of general and bioorganic chemistry" into curriculum just before "Introduction into cell biology". This curriculum and approaches to interdisciplinary education developed at Optics Department were used as a basis in organizing Medical Physics Department of Free Russian-German University in Saratov.

\section{SPECIALTY "BIOPHYSICS"}

Ten-year research and teaching experience in biomedical optics and laser biomedicine allowed to open new specialty at Physics Department of Saratov State University - "Biophysics". This specialty will be divided into two subspecialties: "Biomedical optics" and "Laser biomedicine". The admission procedure to this specialty is in progress now; it is anticipated that the group of students specializing in biophysics will number 15-20 students.

Here we present (see Table 3) a draft version of biophysics curriculum, list of special disciplines of two subspecialties, and the list special practical works on biomedical optics.

Table 3. Draft curriculum for specialty "Biophysics"

\begin{tabular}{|c|c|c|c|c|c|c|c|}
\hline & Exam & $\begin{array}{l}\text { Pass- } \\
\text { exam }\end{array}$ & \multicolumn{5}{|c|}{ Hours } \\
\hline Disciplines & $\begin{array}{r}\text { The nur } \\
\text { the cc } \\
\text { pon } \\
\text { seme }\end{array}$ & $\begin{array}{l}\text { nber of } \\
\text { orres- } \\
\text { ding } \\
\text { ester }\end{array}$ & Total & $\begin{array}{l}\text { Lectu- } \\
\text { res }\end{array}$ & $\begin{array}{l}\text { Labo- } \\
\text { ratory }\end{array}$ & $\begin{array}{l}\text { Prac- } \\
\text { tical } \\
\text { trng }\end{array}$ & $\begin{array}{l}\text { Semi- } \\
\text { nars } \\
\text { /trng }\end{array}$ \\
\hline $\begin{array}{l}\text { 1. Humanitarian and social- } \\
\text { economical } \\
\text { a) history of Russia } \\
\text { b) world history and culture } \\
\text { c) history of natural science } \\
\text { d) history of religion } \\
\text { e) philosophy } \\
\text { f) economics } \\
\text { g) politology } \\
\text { h) fundamentals of law } \\
\text { i) sociology } \\
\text { j) psychology (social) } \\
\text { k) foreign language }\end{array}$ & $\begin{array}{l}4 \\
6 \\
\\
9 \\
4 \\
4\end{array}$ & $\begin{array}{r}7 \\
9 \\
9 \\
3 \\
5 \\
5 \\
8 \\
\\
6 \\
1,2,3 \\
\end{array}$ & $\begin{array}{c}54 \\
54 \\
36 \\
36 \\
116 \\
116 \\
54 \\
34 \\
36 \\
51 \\
210 \\
\end{array}$ & $\begin{array}{l}36 \\
36 \\
36 \\
36 \\
56 \\
54 \\
36 \\
34 \\
34 \\
18 \\
36\end{array}$ & & 210 & $\begin{array}{l}17 \\
17 \\
\\
\\
60 \\
62 \\
18 \\
\\
18 \\
17\end{array}$ \\
\hline $\begin{array}{l}\text { 2. Health protection and } \\
\text { ecology } \\
\text { a) sports } \\
\text { b) fundamentals of healthy } \\
\text { way of living } \\
\text { c) labour protection } \\
\text { d) radioprotection } \\
\text { e) civil defense } \\
\text { f) protection of environment }\end{array}$ & & $\begin{array}{c}1,2,34 \\
5 \\
5 \\
6 \\
5 \\
2\end{array}$ & $\begin{array}{l}280 \\
\\
36 \\
18 \\
34 \\
40 \\
34 \\
\end{array}$ & $\begin{array}{l}36 \\
18 \\
17 \\
40 \\
17\end{array}$ & 17 & 280 & \\
\hline $\begin{array}{l}\text { 3. Introduction into the } \\
\text { specialty }\end{array}$ & & & 18 & 18 & & & \\
\hline 4. Physiology & 8 & & 34 & 34 & & & \\
\hline $\begin{array}{l}\text { 5. Seminar on annual student } \\
\text { project and diploma work }{ }^{*} \text { ) }\end{array}$ & & $\begin{array}{c}2,4,6,8 \\
, 10 \\
\end{array}$ & & & & & \\
\hline $\begin{array}{l}\text { 6. Higher mathematics: } \\
\text { a) mathematical analysis } \\
\text { b) analytical geometry and } \\
\text { higher algebra }\end{array}$ & $\begin{array}{c}1,2,3 \\
2\end{array}$ & $\begin{array}{c}1,2 \\
1 \\
\end{array}$ & $\begin{array}{r}318 \\
105 \\
\end{array}$ & $\begin{array}{c}202 \\
70\end{array}$ & & $\begin{array}{l}106 \\
35 \\
\end{array}$ & \\
\hline
\end{tabular}




\begin{tabular}{|c|c|c|c|c|c|c|}
\hline $\begin{array}{l}\text { c) principles of vector and } \\
\text { tensor analysis } \\
\text { d) differential and integral } \\
\text { equations } \\
\text { e) probability theory and } \\
\text { stochastic processes }\end{array}$ & 3 & 6 & $\begin{array}{l}54 \\
54 \\
51 \\
\end{array}$ & $\begin{array}{l}36 \\
36 \\
34 \\
\end{array}$ & & $\begin{array}{l}18 \\
18 \\
17 \\
\end{array}$ \\
\hline $\begin{array}{l}\text { 7. General physics: } \\
\text { a) mechanics } \\
\text { b) molecular physics } \\
\text { c) electricity and magnetism } \\
\text { d) optics } \\
\text { e) physics of atom } \\
\text { f) nuclear physics and } \\
\text { physics of elementary } \\
\text { particles } \\
\text { g) practical physics }\end{array}$ & $\begin{array}{l}1 \\
2 \\
3 \\
4 \\
5\end{array}$ & $\begin{array}{c}1,2,3,4 \\
, 5,6\end{array}$ & $\begin{array}{c}108 \\
102 \\
108 \\
102 \\
72 \\
\\
34 \\
220 \\
\end{array}$ & $\begin{array}{l}72 \\
68 \\
72 \\
68 \\
54 \\
\\
34\end{array}$ & 210 & $\begin{array}{l}36 \\
34 \\
36 \\
34 \\
18\end{array}$ \\
\hline $\begin{array}{l}\text { 8. Fundamentals of the theory of } \\
\text { oscillations }\end{array}$ & 4 & & 85 & 34 & 34 & 17 \\
\hline 9. Biochemistry & 7 & & 36 & 36 & & \\
\hline $\begin{array}{l}\text { 10. Theoretical physics: } \\
\text { a) methods of mathematical } \\
\text { physics } \\
\text { b) analytical mechanics } \\
\text { c) theory of continuous } \\
\text { media } \\
\text { d) electrodynamics } \\
\text { e) quantum mechanics } \\
\text { f) solid state physics } \\
\text { g) thermodynamics of living } \\
\text { systems } \\
\end{array}$ & $\begin{array}{l}6 \\
7 \\
8 \\
7 \\
\end{array}$ & $\begin{array}{l}4 \\
6 \\
6 \\
5 \\
6\end{array}$ & $\begin{array}{l}88 \\
54 \\
\\
34 \\
71 \\
71 \\
34 \\
70\end{array}$ & $\begin{array}{l}53 \\
36 \\
\\
34 \\
36 \\
36 \\
34 \\
35 \\
\end{array}$ & & $\begin{array}{l}35 \\
35\end{array}$ \\
\hline 11. Biophysics & 7 & & 126 & 54 & 54 & 18 \\
\hline $\begin{array}{l}\text { 12. Nonlinear oscillations and } \\
\text { selforganization in } \\
\text { biophysics }\end{array}$ & & 8 & 68 & 34 & & 17 \\
\hline $\begin{array}{l}\text { 13. Introduction into cell } \\
\text { biology }\end{array}$ & & 4 & 34 & 34 & & \\
\hline $\begin{array}{l}\text { 16. Informatics: } \\
\text { a) computers and } \\
\text { programming } \\
\text { b) computational methods } \\
\text { in biophysics } \\
\text { c) information technologies } \\
\text { and knowledge bases } \\
\text { d) numerical simulation in } \\
\text { biophysics } \\
\text { e) system analysis } \\
\text { f) computer-aided research } \\
\text { and development } \\
\end{array}$ & 8 & $\begin{array}{l}1 \\
4 \\
5\end{array}$ & $\begin{array}{l}70 \\
34 \\
36 \\
51 \\
54 \\
36\end{array}$ & $\begin{array}{l}53 \\
17 \\
18 \\
17 \\
36 \\
18\end{array}$ & $\begin{array}{l}17 \\
18 \\
34 \\
18 \\
\end{array}$ & 18 \\
\hline $\begin{array}{l}\text { 15. Radioengineering in } \\
\text { biophysics }\end{array}$ & & 9 & 36 & 36 & & \\
\hline $\begin{array}{l}\text { 16. General and bioorganic } \\
\text { chemistry }\end{array}$ & 6 & & 68 & 34 & 17 & 17 \\
\hline $\begin{array}{l}\text { 17. Disciplines of } \\
\text { specialization }\end{array}$ & $\begin{array}{l}6,7,8 \\
8,9,9\end{array}$ & \begin{tabular}{|c|}
$6,7,7,7$ \\
$, 7,8,8$ \\
$8,9,9$ \\
9 \\
\end{tabular} & & & & \\
\hline
\end{tabular}


*) Diploma work $\approx$ master's thesis. At the end of the first, second, third, and fourth year - defense of the annual student projects.

\author{
List of disciplines of specialization \\ for subspecialties "Biomedical optics" \\ and \\ "Laser biomedicine" ("Biophysics specialty").
}

Theory of radiation

Medical optoelectronics

Biotissue optics

Theoretical optics

Foundations of biochemistry and biophysics of photobiological processes

Statistical optics

Atomic and molecular spectroscopy

Molecular optics

Diffraction methods in biomedicine

Nonlinear optics

Luminescence

Spectroscopy of bio-objects

General pathology and principles of application of lasers to medicine

Lasers in ophthalmology

Laser and optical methods in dermatology

Holography and interferometry in biomedicine

Optical microscopy and tomography

Special practical physics - 1 "Spectral devices and optical spectroscopy techniques"

Special practical physics - 2 "Lasers and holography"

Special practical physics - 3 "Biomedical optics"

List of practical works of special practical physics 3

"Biomedical optics" for specialty "Biophysics"

1. Computer-aided coherent scanning microscope

2. Laser speckle-anemometer for biological fluids diagnostics

3. Methods of speckle-optics for biovibration detection

4. Laser interferometric retinometer

5. Colorimetric erythemometer

6. In vivo frequency-domain study of photon migration in biotissue

7. Determination of optical parameters of human epidermal layers using spectrometer with integrating sphere

8. Photogoniometric measurements on biotissues

9. Spectrofluorimetric study of human epidermis

Besides, faculty and technicians of optical department updated some works of basic practical biophysics (7 semester) and offered some new works. Among them are:

Determination of electrophoretic mobility of red blood cells

Study of photodynamic haemolysis of erythrocytes

Nefelometric study of immunoreations

Study of optical activity of biomolecular solutions

Determination of electroconductivity of bioobjects

The curriculum will be introduced during five years. We opened new specialty and developed the curriculum keeping in mind the idea of bringing fundamental biophysics (and biomedical optics as a part of it) closer to clinical and biomedical research practice, as we expect that research laboratories at clinics as well as research and development departments at medical equipment manufacturers can offer new working places to University graduates. 


\section{CAREER OPPORTUNITIES FOR GRADUATES}

The graduates of Optics Department of Saratov University who specialized in biomedical optics may get positions at clinics of Saratov Medical University where laser equipment is more and more widely used and research projects in laser biomedicine are performed, or at research and design departments of large researchproductive amalgamations. Great amount of graduates joins the staff of laboratories of institutes of Russian Academy of Sciences; for example, almost all researches of Laboratory of Laser Medicine of Radioengineering and Electronics Institute are the graduates of Optics Department. Rapid growth of small business in Russia offers new positions at joint ventures that works in medicine and with medical equipment; some graduates have already got there positions of experts on the staff. Graduates actively and with good results working as researchers in biomedical optics may enter post-graduate course (three-year term) to work at Candidate Thesis or join Optics Department for one-year term to prepare Doctor of Science Thesis (those who have Candidate degree).

Also, the idea of continuity of education is embodied in the project developed at the Optics Department; the aim of which is to organize at Saratov State University the International Education \& Technology Center of Small Business (E\&T Center), which could provide training and improving qualification of beginners in small science-based business. Within the E\&T Center a specialized training center in laser medical technologies is suggested. It is supposed that this business \& technology center will promote small science-based business in Russia and opening new positions for highly skilled personnel of defense industry enterprises undergone conversion and Saratov schools graduates.

\section{ACKNOWLEDGMENTS}

Many thanks to Associate Professors R.Mukhamedov and A.Velichko for their help in preparation of curricula and to Professor V.Anischenko for fruitful discussions.

\section{REFERENCES}

1. W.G.Janssen The Role of a Biomedical Laser Specialist, Proc.SPIE, Vol.1650, Medical lasers and Systems, 1992, pp. 150-155.

2. V.Ryabukho, V.Tuchin Fundamentals and curriculum of education on optical and laser metrology, Proc. SPIE, vol. 2525 , paper \# 51, 1995.

3. S.Ul'ayanov, V.Tuchin, S.Kuzmin, A.Bednov Teaching of diffraction methods in biomedicine to undergraduates specializing in optics, Proc. SPIE, vol. 2525, paper \# 90, 1995.

4. A.V.Priezzhev, V.V.Tuchin, L.P.Shubochkin Laser Diagnostics in Biology and Medicine, Nauka Publishers, Moscow, 1989. (in Russian) 1982.

5. P.R.Carey Biochemical Applications of Raman and Resonance Raman Spectroscopies, Academic Press,

6. A.B.Rubin Biophysics, Vol.2, Biophysics of cell processes, Vysshaya Shkola, Moscow, 1987.(in Russian)

7. V.V.Tuchin. Lasers and fiber optics in biomedicine. Laser Physics, vol.3, N4, pp 767-820; N5, pp. 925950, 1993.

8.V.V.Tuchin. Laser light scattering in biomedical diagnostics and therapy. J.Laser Applications (Laser Inst. of America), vol.5, N2 \& 3, pp. 43-60, 1993.

9. V.V.Tuchin. Lasers and fiber optics in biomedicine. Saratov Univ. Publ., (Saratov Univ. Publ.- M., Inotec-Progress, 1993, floppy- disk, in Russian).

10. Yu.A.Vladimirov, A.Ya.Potapenko Physico-chemical foundations of photobiological processes, Vysshaya Shkola, Moscow, 1989. (in Russian) 